\title{
Histone-Binding Protein RBBP4
}

National Cancer Institute

\section{Source}

National Cancer Institute. Histone-Binding Protein RBBP4. NCI Thesaurus. Code C101728.

Histone-binding protein RBBP4 (425 aa, $\sim 48 \mathrm{kDa}$ ) is encoded by the human RBBP4 gene.

This protein is involved in transcriptional regulation, cell proliferation and histone binding. 